\title{
PENINGKATAN KUALITAS CABAI MERAH KERING DENGAN PERLAKUAN BLANCHING DALAM NATRIUM METABISULFIT
}

\author{
(Increasing quality of dried red chili Pepper by Blanching treatment in solutionof natrium \\ metabisulfite)
}

\author{
Ridwan $^{1}$, Agus Arip Munawar ${ }^{1}$, Rita Khathir ${ }^{\text {* }}$ \\ ${ }^{1}$ Program Studi Teknik Pertanian, Fakultas Pertanian, Universitas Syiah Kuala
}

\begin{abstract}
Abstrak.Mutu cabai kering perlu ditingkatkan sehingga masyarakat mau menggunakan cabai kering sebagai pengganti cabai segar. Penelitian ini bertujuan untuk mengkaji mutu cabai merah kering yang diberi perlakuan blanching dengan variasi konsentrasi larutan natrium metabisulfit sebelum proses pengeringannya. Variasi konsentrasi yang diuji adalah $0 \%, 0,2 \%$ dan $0,3 \%$. Pengeringan cabai merah dilakukan dengan menggunakan alat pengering terowongan surya tipe Hohenheim termodifikasi. Proses pengeringan berlangsung selama 3 hari dengan rentang waktu yang berbeda yang diakibatkan oleh tahapan perlakuan pra pengeringan yaitu blanching dan kondisi hujan, dimana total waktu pengeringan adalah $10 \mathrm{jam}$. Hasil penelitian menunjukkan bahwa selama proses pengeringan terjadi fluktuasi iradiasi surya dimana rata-rata iradiasi surya tertinggi diperoleh pada hari ketiga yaitu sebasar $383,73 \mathrm{~W} / \mathrm{m}^{2}$. Pengeringan menggunakan alat pengering tipe Hohenheim berlangsung dengan rentang temperatur pengeringan $42-62{ }^{\circ} \mathrm{C}$, RH $26-78 \%$, dan kecepatan udara yang sangat rendah. Peningkatan konsentrasi larutan natrium metabisulfit mempercepat penurunan kadar air sehingga mempercepat proses pengeringan.Vitamin $\mathrm{C}$ cabai kering menurun setelah pengeringan sebagai akibat terpaparnya cabai kering terhadap temperatur pengeringan. Rendemen cabai kering menurun dengan peningkatan konsentrasi larutan natrium metabisulfit. Berdasarkan analisis warna, warna tercerah diperoleh pada cabai merah kering perlakuan blanching dalam larutan natrium metabisulfit dengan konsentrasi $0,2 \%$.
\end{abstract}

Kata kunci : Cabai merah, blanching, natrium metabisulfit, dan pengering terowongan surya tipe Hohenheim

\begin{abstract}
The quality of dried red chili pepper have to improve so that the people will use dried red chili pepper as alternative to fresh red chili pepper. The study aimed to evaluate the quality of dried red chili pepper after blanching in solution of sodium metabisulfite at different concentration i.e. 0 , 0.2 , and $0.3 \%$. The drying process was done by using modified solar tunnel Hohenheim type dryer.The complete drying process needed 3 days at different durration and the total time used was about 10 hours due to the preparation of blanching treatment and rainy day. Results showed that during the drying process there was high fluctuation of solar irradiation, where the highest average of solar irradiation occurred on the third day, $383.73 \mathrm{~W} / \mathrm{m}^{2}$. The drying temperature ranged from 42 to $62{ }^{\circ} \mathrm{C}$ and the relative humidity ranged from 26 to $78 \%$. However the air velocity in the drying chamber was very low. The increase of concentration of sodium metabusulfite solution caused the higher water loss therefore shortern the drying process. The vitamin $\mathrm{C}$ of dried red chili decreased at all concentration treated due to the high temperature during drying process. The yield of dried red chili decreased as the increase of concentration of sodium metabusulfite solution. The bright colour of dred red chili was gained by using concentration of sodium metabusulfite solutionat $0.2 \%$.
\end{abstract}

Keywords: Red Chili Pepper, blanching, sodium metabisulfite, solar tunnel Hohenheim type drier

\section{PENDAHULUAN}

Cabai merah(Capsicum annum L) merupakan salah satu tanaman sayuran penting di Indonesiayang mampu memenuhi kebutuhan khas masyarakat Indonesia akan rasa pedas dari suatu masakan.Cabai merah juga memberikan warna dan rasa yang dapat membangkitkan 
selera makan, banyak mengandung vitamin dan dapat juga digunakan sebagai obat-obatan, serta sebagai bahan campuran pada makanan.

Sifat cabai merah sama seperti produk holtikultura lainnya yang merupakan produk yang mudah mengalami kerusakan, baik kerusakan mikrobiologis, kerusakan fisiologis maupun kerusakan akibat cara penanganan pasca panen yang kurang tepat. Untuk menghindari kerugian yang diakibatkan oleh terjadinya kerusakan tersebut maka perlu dilakukan tindakan-tindakan yang dapat mencegah terjadinya kerusakan diantaranya melalui pengolahan. Tujuan pengolahan antara lain adalah untuk mengawetkan produk pertanian agar dapat disimpan dalam waktu yang lama. Salah satu cara untuk mengawetkan cabai adalah dengan metode pengeringan (Ali dkk., 2002).

Salah satu alat pengering cabai yang dapat digunakan yaitu alat pengering tipe Hohenheim. Keuntungan melakukan pengeringan dengan menggunakan alat pengering jenis terowongan ini yaitu dapat mencegah kontaminasi dengan lingkungan sehingga dapatmenghasilkan produk yang baik, selain itu juga mempercepat waktu pengeringan karena temperatur pada alat pengering tersebut lebih tinggi dari pada temperatur lingkungan (Gayo, 2015).

Menurut Yani dan Ratriningsih (1997), pengaruh blanching sebelum cabai merah dikeringkan yaitu dapat mempercepat waktu pengeringan, mencegah browning dan memperpanjang umur simpan. Penggunaan larutan natrium metabisulfit dimaksudkan untuk memperbaiki dan mempertahankan warna cabai merah kering yang dihasilkan. Oleh karena itu penelitian ini dilakukan dengan fokus kajian pada proses blanching cabai merah dalam larutan natrium metabisulfit dengan variasi konsentrasinyasebelum proses pengeringan.

\section{METODE PENELITIAN \\ Waktu dan Tempat}

Penelitian ini dilaksanakan pada bulan Juni - Desember 2016 dengan mengambil beberapa tempat yaitu Laboratorium Teknik Pasca Panen Program Studi Teknik Pertanian, Laboratorium Analisis Pangan Program Studi Teknologi Hasil Pertanian, dan Kebun Percobaan Fakultas Pertanian Universitas Syiah Kuala Banda Aceh.

\section{Alat dan Bahan}

Alat-alat yang digunakan pada penelitian ini adalah pengering terowongan tipe Hohenheim, baskom plastik, solari meter, anemometer, timbangan digital, termometer, humidity meter, dan water bath.

Bahan baku yang digunakan pada penelitian ini adalah cabai merah besar dengan varietas cabai keriting yang diperoleh dari petani Grong Grong Kabupaten Pidie sebanyak 9 $\mathrm{kg}$, natrium metabisulfit sebanyak $35 \mathrm{~g}$, dan air sebanyak 42 liter .

\section{Prosedur Penelitian}

Tahapan pertama penelitian ini adalah sortasi dan pencucian cabai merah yang dibeli dari petani daerah Grong Grong Kabupaten Pidie Propinsi Aceh. Sebanyak 50 g sampel cabai diambil untuk analisis kadar air awal. Perlakuan yang diberikan adalah blanching dengan variasi konsentrasi larutan natrium metabisulfit yaitu $0 \%, 0,2 \%$ dan $0,3 \%$ untuk setiap $1 \mathrm{~kg}$ cabai. Proses blanching dilakukan dalam water bath pada temperatur $90^{\circ} \mathrm{C}$ selama 10 menit. Terdapat 3x ulangan per perlakuan sehingga total cabai merah yang digunakan adalah $9 \mathrm{~kg}$. Setelah proses blanching diambil lagi sampel sebanyak $50 \mathrm{~g}$ untuk analisis kadar air. Selanjutnya pengeringan dilakukan menggunakan alat pengering tipe Hoheinheim. Selama proses pengeringan dilakukan pengamatan terhadap iradiasi surya, temperatur, kelembaban 
relatif, kecepatan udara, dan perubahan berat sampel. Pengamatan tersebut dilakukan dalam interval waktu 30 menit. Pengeringan dilakukan sampai kadar air cabai merah maksimal 10\%. Adapun parameter penelitian yang diamati pada cabai kering adalah kadar air, vitamin $\mathrm{C}$, rendemen dan warna.

\section{Parameter Penelitian}

\section{Iradiasi Surya}

Iradiasi surya adalah jumlah energi surya dari waktu ke waktu. Lokasi yang berbedabeda memiliki berbagai tingkat iradiasi. Pengukuran iradiasi surya diukur dengan menggunakan solarimeter. Data pengamatan didapat dalam $(\mathrm{mV})$ kemudian dikonversi dalam satuan Watt $/ \mathrm{m}^{2}$ dengan menggunakan Persamaan 1.

$$
R=\frac{\text { Data Hasil Pengukuran }(\mathrm{mV})}{17,2\left(\mathrm{mV} / \mathrm{kW} / \mathrm{m}^{2}\right)} \times 1000
$$

Dimana: $\mathrm{R}$ adalah iradiasi surya $\left(\mathrm{W} / \mathrm{m}^{2}\right)$

\section{Temperatur}

Pengukuran temperatur dilakukan dengan menggunakantermometer. Temperatur yang diukur pada penelitian ini meliputi temperatur lingkungan dan ruang pengering. Pengukuran temperatur dilakukan selama proses pengeringan setiap 30 menit.

\section{Kelembaban Relatif}

Perhitungan kelembaban relatif dilakukan dengan menggunakan alat digital yaitu humidity meter dengan merk Chino. Pada penelitian ini kelembaban relatif diukur meliputi kelembaban relatif lingkungan dan kelembaban relatif ruang pengering. Pengukuran kelembaban relatif dilakukan selama proses pengeringan berlangsung dengan interval 30 menit.

\section{Kecepatan Udara}

Alat untuk mengukur kecepatan udara adalah anemometer. Udara yang diukur yaitu udara lingkungan dan udara ruang pengering. Pengukuran kecepatan udara dilakukan dalam rentang waktu setiap 30 menit selama proses pengeringan.

\section{Berat Bahan}

Penimbangan berat sampel dilakukan setiap 30 menit sekali selama proses pengeringan berlangsung.

\section{Kadar Air}

Analisis kadar air awal cabai merah, kadar air cabai merah setelah blanching dan kadar air cabai kering dilakukan dengan metode oven dengan prosedur pengeringan pada temperatur $105^{\circ} \mathrm{C}-110^{\circ} \mathrm{C}$ selama 12 jam sampai berat sampel yang diperoleh konstan.

$$
\begin{aligned}
& K A_{b b}=\frac{m_{1}-m_{2}}{m_{1}} \times 100 \% \ldots \\
& \text { Dimana: } \\
& \mathrm{m}_{1}=\text { berat awal bahan }(\mathrm{g}) \\
& \mathrm{m}_{2}=\text { berat kering bahan }(\mathrm{g})
\end{aligned}
$$




\section{Vitamin C}

Penentuan vitamin ini ditentukan dengan metode titrasi iodin. Mula-mula $50 \mathrm{~g}$ filtratsampel disaring menggunakan kertas saring ( 2 kali penyaringan), kemudian dititrasi dengan larutan iod 0,01 N. Indikator kanji ditambahkan pada filtrat sebelum dilakukan titrasi. Titrasi dilakukan sampai terjadi perubahan warna yang stabil (bentuk warna biru ungu).

Vit $C=\frac{\operatorname{mliod} 0,01 N \times 0,88 \times 100 \times p}{W}$

Dimana :

$\mathrm{p}=$ Faktor pengencer, 10

$\mathrm{W}=$ Berat sampel $(\mathrm{g})$

\section{Rendemen}

Rendemen dapat dihitung dengan Persamaan 4.

$$
R=\frac{S}{P} \times 100 \%
$$

Dimana;

$\mathrm{R}=$ Rendemen $(\%)$

$\mathrm{S}=$ Berat cabai kering $(\mathrm{g})$

$\mathrm{P}=$ Berat cabai segar $(\mathrm{g})$

\section{Pemotretan Gambar}

Pemotretan sampel dilakukan dengan menggunakan kamera digital 18 mega pixel dimana sampel diletakkan dalam kotak berwarna hitam yang berbentuk segi empat dengan penambahan lampu pijar sebesar 5 watt.

\section{Teknik Analisa Data}

\section{Analisis Deskriptif}

Data penelitian ini ditampilkan secara deskriptif dalam bentuk tabel dan grafik. Sebagai tambahannya digunakan analisis statistik deskriptif meliputi nilai rata-rata, nilai maksimum, nilai minimum, dan standar deviasi.

\section{Perhitungan Kadar Air}

Perhitungan kadar air dilakukan berdasarkan analisis kadar air cabai segar pasca blanching yaitu $81,4 \%$. Berdasarkan analisis kadar air maka dapat dihitung nilai berat kering bahan. Dengan berat sampel yang dikeringkan sebesar $50 \mathrm{~g}$ maka didapat bahwa berat keringnya adalah $9,3 \mathrm{~g}$.

$$
K A_{\text {hit }}=\frac{m_{i}-b k}{m_{i}} \times 100 \%
$$

Dimana:

$\mathrm{m}_{\mathrm{i}} \quad$ = Berat cabai pada jam ke $\mathrm{i}(\mathrm{g})$

bk = Berat kering cabai $(\mathrm{g}), 9,3 \mathrm{~g}$

$\mathrm{KA}_{\text {hit }}=$ Kadar air secara perhitungan $(\%)$ 


\section{Analisis Warna}

Berdasarkan hasil pemotretan sampel, kemudian dilakukan analisis L, a, b menggunakan software photoshop. Prosesnya diawali dengan melihat nilai R (red), G (green) dan B (blue) dari gambar yang diperoleh menggunakan Persamaan 6. Kemudian dihitung nilai X, Y dan Z dengan menggunakan Persamaan 7, 8 dan 9. Selanjutnya nilai L, a dan b dihitung dengan Persamaan 10, 11, dan 12 .

$\mathrm{R}=\frac{R a}{255} \quad \mathrm{G}=\frac{G a}{255} \quad \mathrm{~B}=\frac{B a}{255}$

$\mathrm{X}=0.607 \mathrm{R}+0.174 \mathrm{G}+0.201 \mathrm{~B}$

$\mathrm{Y}=0.299 \mathrm{R}+0.587 \mathrm{G}+0.114 \mathrm{~B}$

$\mathrm{Z}=0.066 \mathrm{G}+1.117 \mathrm{~B}$

$\mathrm{L}=25\left(\frac{100 Y}{100}\right)^{1 / 3}-16$

$a=500\left[\left(\frac{X}{98.071}\right)^{1 / 3}-\frac{Y}{100}\right]^{1 / 3}-16$

$\mathrm{b}=200\left[\left(\frac{Y}{100}\right)^{1 / 3}-\left(\frac{Z}{118.225}\right)\right]^{1 / 3}$

Nilai $L^{*} a * b$ tersebut diplotkan pada diagram $L^{*} a * b$ untuk memperoleh warna cabai merah. Makna dari setiap dimensi yang dibentuk yaitu :

1. Dimensi L untuk mendeskripsikan kecerahan warna, 0 untuk hitam dan $\mathrm{L}=100$ untuk putih

2. Dimensi a mendeskripsikan jenis warna hijau-merah, dimana angka a negatif mengindikasikan warna hijau dan sebaliknya jika a positif mengindikasikan warna merah.

3. Dimensi $b$ untuk jenis warna biru-kuning, dimana angka $b$ negatif mengindikasikan warna biru dan sebaliknya jika b positif mengindikasikan warna kuning.

\section{HASIL DAN PEMBAHASAN}

\section{Deskripsi Pengeringan}

Proses pengeringan cabai merah segar dilakukan pada tanggal 10 Juni - 13 Juni 2016, dimana pengeringan berlangsung selama 3 hari dengan rentang waktu yang berbeda. Proses pengeringan bersifat intermitten, yaitu hanya dilangsungkan di siang hari, dimana pada waktu malam hari cabai merah diangkat dari alat pengering dan disimpan dalam kantung plastik.

Proses pengeringan cabai merah segar hari pertama berlangsung selama 3,5 jam dimulai pada pukul 14.00 - 17.30 WIB, pada hari kedua berlangsung selama 3,5 jam di mulai pada pukul 12.00 - $15.30 \mathrm{WIB}$, sedangkan pada hari ketiga berlangsung selama 3 jam dimulai pada pukul 08.00 hingga berakhir pada pukul 11.00 WIB. Dengan demikian total waktu pengeringan cabai merah menggunakan alat pengering tipe Hohenheim adalah $10 \mathrm{jam}$. Dokumentasi pada saat proses pengeringan dapat dilihat pada Gambar 1. 


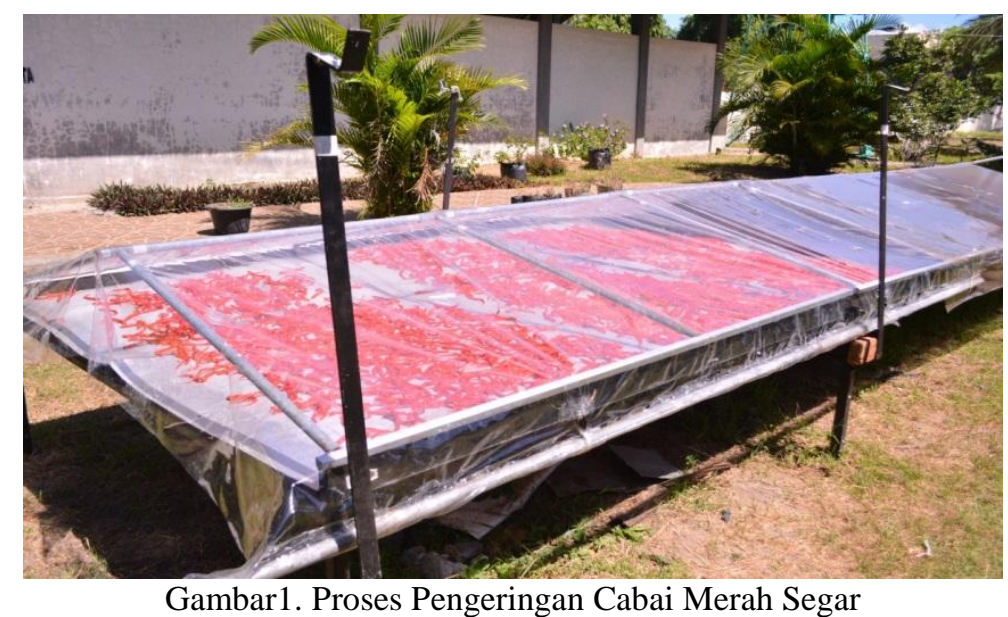

\section{Iradiasi Surya}

Berdasarkan Gambar 2 dapat dilihat bahwa terjadi fluktuasi cuaca selama proses pengeringan cabai merah, dimana kondisi pengeringan terbaik diperoleh pada hari ketiga pengeringan dengan rata-rata iradiasi surya sebesar $383,73 \mathrm{~W} / \mathrm{m}^{2}$. Berdasarkan pengamatan selama penelitian ini, iradiasi surya berpotensi tinggi nilainya antara pukul 09.00-13.00 WIB. Iradiasi surya berfluktuasi sepanjang waktu karena dipengaruhi oleh posisi matahari dan kecerahan langit. Hal ini terlihat dari tingginya stadar deviasi data amatan nilai iradiasi surya yaitu dalam kisaran 90-205 W/m². Kondisi maksimum iradiasi surya dicapai pada cuaca baik dengan langit cerah yang memungkinkan radiasi surya yang dipancarkan dapat diserap lebih banyak ke bumi.

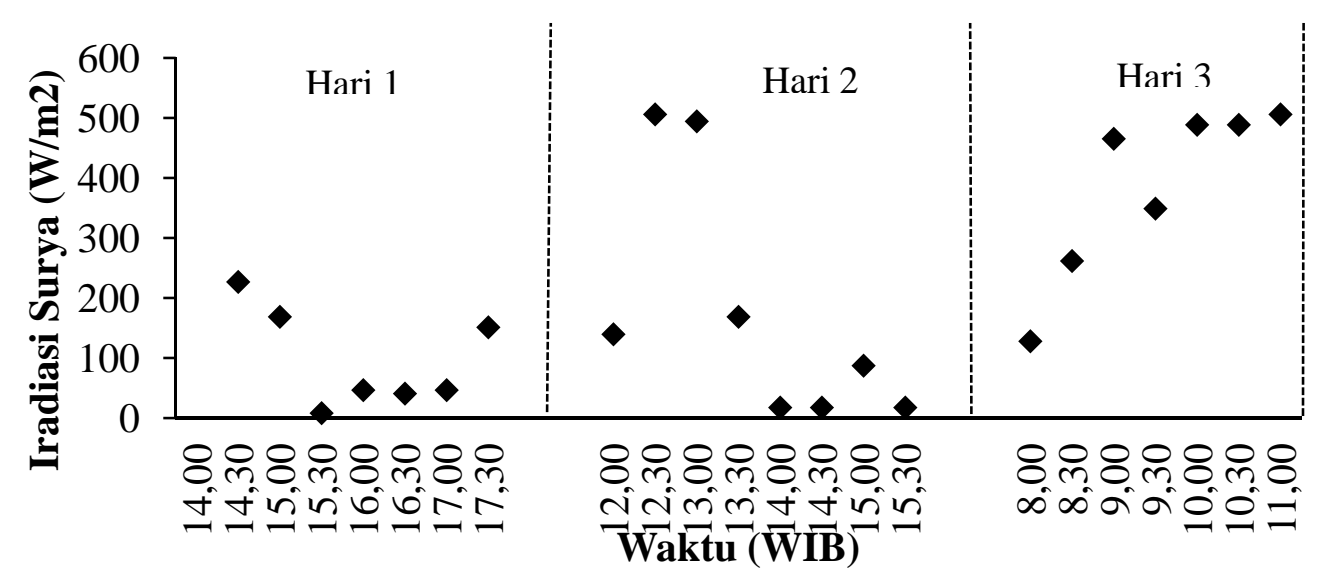

Gambar 2. Iradiasi Surya Selama Pengeringan Cabai Merah

\section{Temperatur Pengeringan}

Temperatur selama proses pengeringan hari pertama hingga hari ketiga dapat dilihat pada Gambar 3. Pada hari pertama pengeringan, temperatur rata-rata pada alat pengering sebesar $50,75^{\circ} \mathrm{C}$. Sedangkan temperatur lingkungan rata-rata yang didapat sebesar 
$35,75^{\circ} \mathrm{C}$.Temperatur rata-rata pada hari kedua pengeringan pada alat pengering sebesar $42,13^{\circ} \mathrm{C}$ sedangkan pada lingkungan diperoleh sebesar $31^{\circ} \mathrm{C}$. Adapun pada hari ketiga, temperatur pada alat pengering sebesar $62,43^{\circ} \mathrm{C}$, sedangkan pada lingkungan sebesar $36,43^{\circ} \mathrm{C}$.

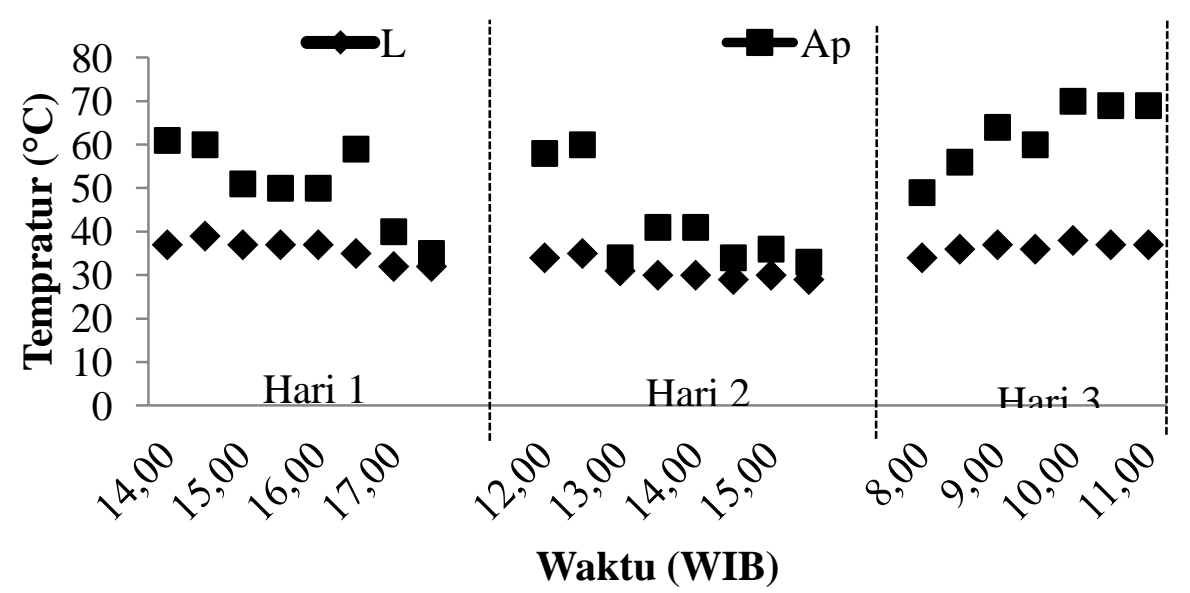

Keterangan :

$\mathrm{L}:$ di luar alat pengering

Ap : di dalam alat pengering

Gambar 3. Temperatur Selama Pengeringan Cabai Merah

Dapat disimpulkan bahwa temperatur pengering pada alat pengering lebih tinggi dari pada temperatur lingkungan. Hal ini menunjukkan bahwa design alat pengering tipe Hohenheim berhasil menaikkan temperatur pengeringan berdasarkan iradiasi surya dan sangat layak digunakan untuk peningkatan teknologi pengeringan produk pertanian seperti cabai merah.

\section{Kelembaban Relatif Udara Pengering}

Kelembaban udara pengering $(\mathrm{RH})$ sangat berperan penting dalam proses pengeringan karena kelembaban udara menunjukkan kandungan uap air yang ada di udara. Semakin tinggi kandungan uap air dalam udara, akan semakin memperlambat proses pengeringan. Nilai hasil pengukuran RH selama proses pengeringan dapat dilihat pada Gambar 4. 


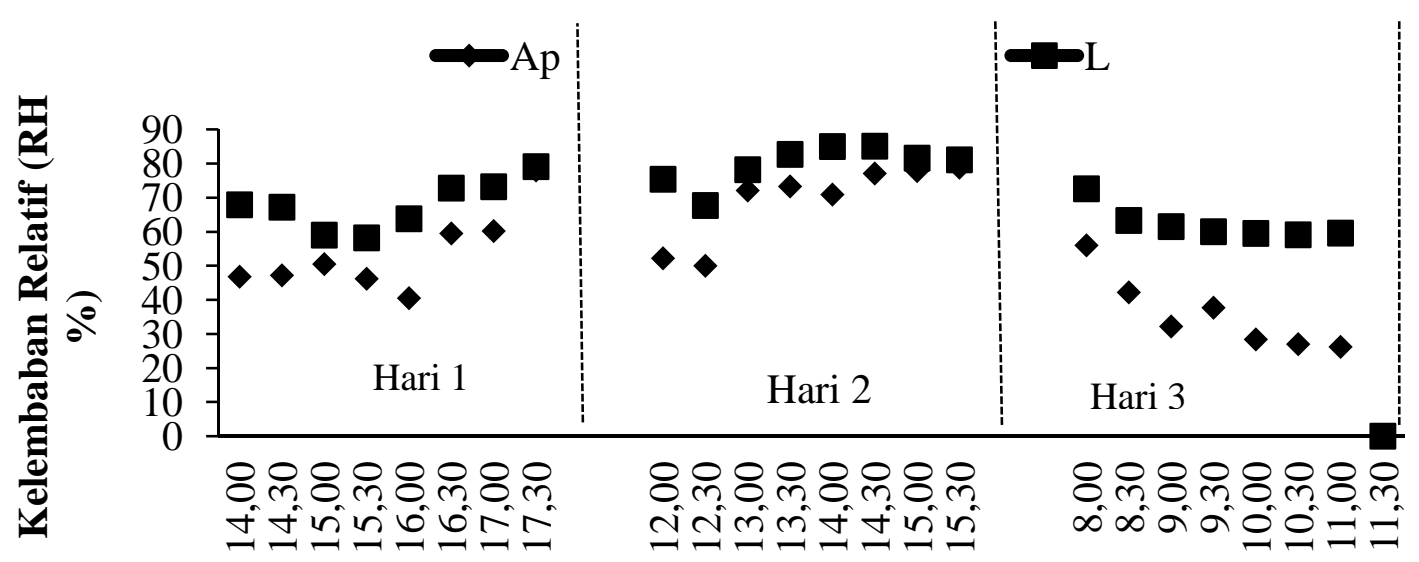

Keterangan :

Waktu (WIB)

$\mathrm{L}:$ di luar alat pengering

Ap : di dalam alat pengering

Gambar 4. Kelembaban Relatif Selama Pengeringan Cabai Merah

Selama tiga hari pengeringan, nilai rata-rata kelembaban relatif (RH) di lingkungan lebih tinggi dari RH dalam alat pengering. Hal ini sesuai dengan hasil pengamatan temperatur yang menunjukkan bahwa temperatur dalam ruang pengering jauh lebih tinggi dari temperatur lingkungan. Fluktuasi RH terjadi selama proses pengeringan sesuai dengan fluktuasi temperatur tersebut. Dalam hal ini, Thahir (1988) yang menyatakan bahwa semakin tinggi tempratur maka kelembaban relatif $(\mathrm{RH})$ akan semakin rendah.

\section{Kecepatan Udara}

Hasil pengukuran kecepatan udaraselama pengeringan cabai merah dapat dilihat pada Gambar 5. Berdasarkan data kecepatan udarayang diperoleh dapat dilihat bahwa kecepatan udara pada ruang pengering selama proses pengeringan kecepatan udara rata-rata pada ruang alat pengering berlangsung sangat rendah, tidak lebih dari $0,1 \mathrm{~m} / \mathrm{s}$.Namun bisa dipastikan selama proses pengeringan terdapat aliran udara yang mengalir melewati ruang pengering dikarenakan adanya 3 buah kipas pada alat pengering, yang masing-masingnya mengalirkan udara ke ruang pengering dengan kecepatan $2 \mathrm{~m} / \mathrm{s}$. Sedangkan kecepatan udara lingkungan rata-rata hari pertama pengeringan didapat sebesar $1,15 \mathrm{~m} / \mathrm{s}$, pada hari kedua pengeringan didapat sebesar $1,51 \mathrm{~m} / \mathrm{s}$, dan kecepatan udara lingkungan pada hari ketiga pengeringan didapat nilai rata-rata sebesar $1,1 \mathrm{~m} / \mathrm{s}$. 


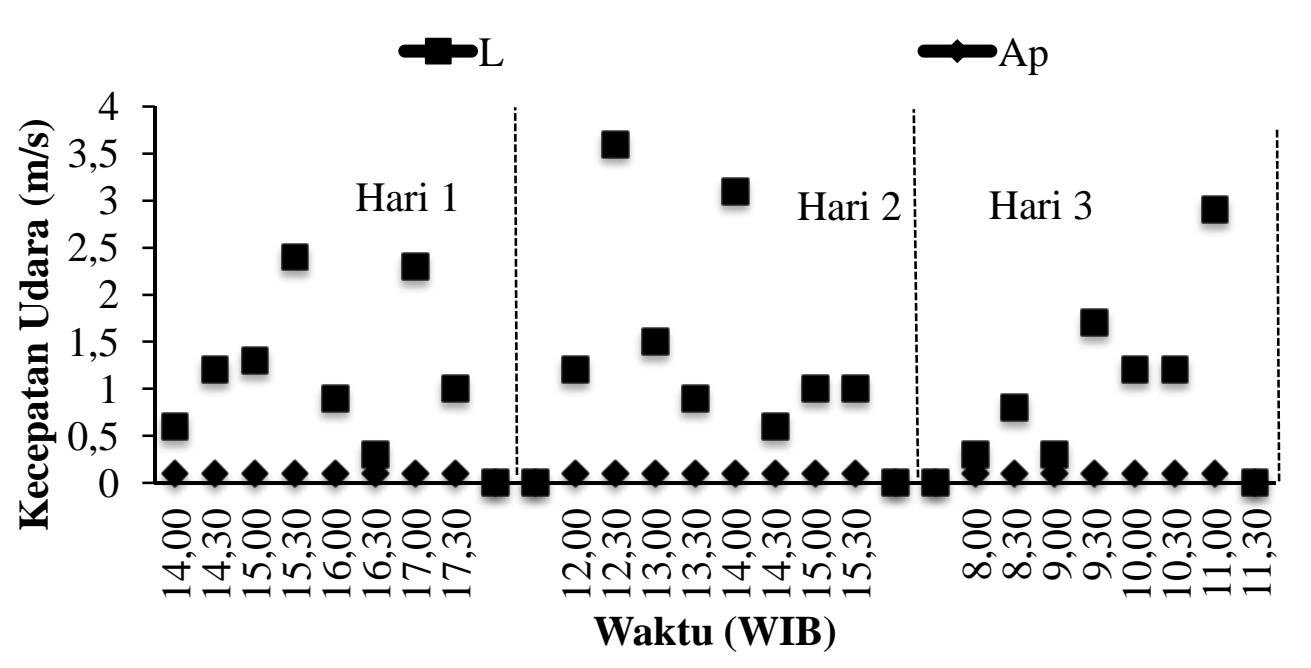

Keterangan :

$\mathrm{L}:$ di luar alat pengering

Ap : di dalam alat pengering

Gambar 5. Kecepatan Udara Selama Pengeringan Cabai Merah

Kecepatan aliran udara sangat berpengaruh pada saat proes pengeringan karena udara berfungsi sebagai penghantar panas dan sebagai pengikat kandungan uap air yang telah diambil dari bahan, sehingga semakin cepat aliran udara maka semakin cepat pula proses pengeringan. Hal ini didukung oleh pernyataan Taib dkk (1988), bahwa salah satu faktor yang mempercepat proses pengeringan adalah kecepatan angin atau udara yang mengalir. Semakin cepat aliran udara semakin cepat pengeringan berlangsung, bila udara tidak mengalir maka kandungan uap air disekitar bahan yang dikeringkan makin jenuh sehingga pengeringan makin lambat.

\section{Perubahan Kadar Air selama Pengeringan}

Berdasarkan uji kadar air di laboratorium, diperoleh informasi kadar air awal cabai merah segar yaitu sebesar $82,4 \%$, sedangkan setelah proses blanching, kadar air cabai merah menjadi $81,4 \%$. Penurunan kadar air selama proses pengeringan dapat dilihat pada Gambar 6.

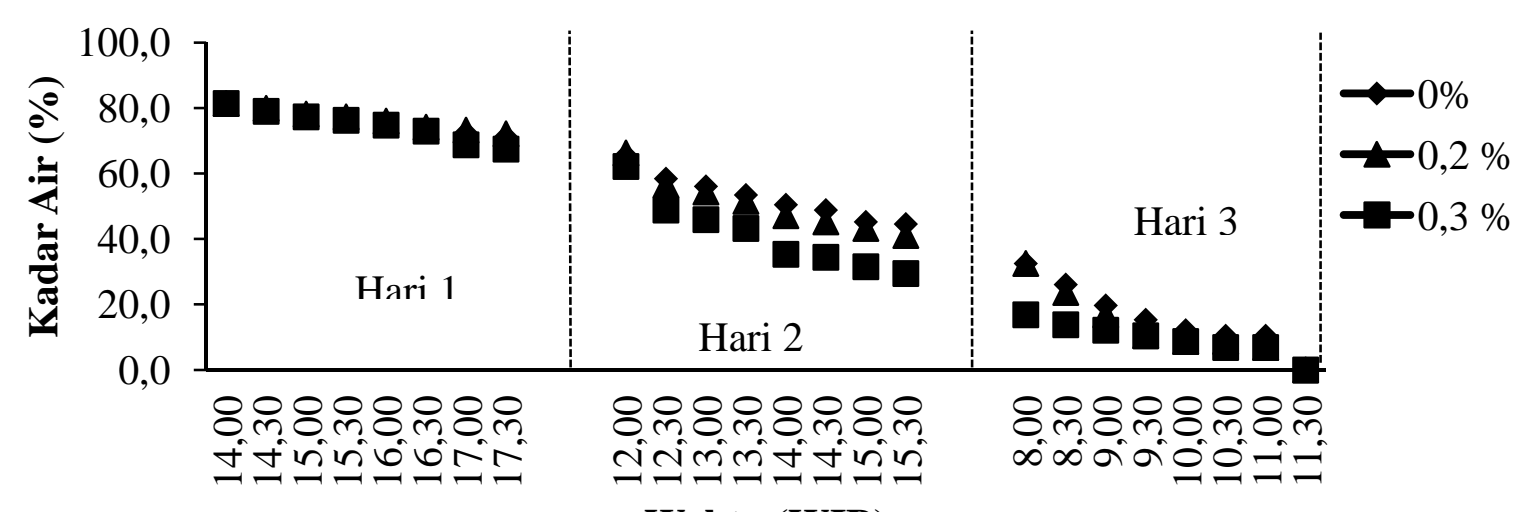

Waktu (WIB)

Gambar 6. Kadar Air Cabai Merah Selama Pengeringan

Kadar air awal cabai merah pada hari ketiga pengeringan perlakuan blanching dengan larutan natrium metabisulfit pada konsentrasi 0 dan $0,2 \%$ adalah $32,5 \%$, sedangkan kadar air awal cabai merah perlakuan blanching dengan larutan natrium metabisulfit pada konsentrasi 
$0,3 \%$ adalah $16,8 \%$. Terdapat perbedaan antara kadar air akhir cabai merah setelah pengeringan hari kedua dan kadar air awal cabai merah pada pengeringan hari ketiga, yang dapat disebabkan oleh proses penimbangan sampel pada suhu yang berbeda dan terjadinya desorpsi. Adapun kadar air akhir cabai merah pada hari ketiga pengeringan perlakuan blanching dengan larutan natrium metabisulfit pada konsentrasi $0 \%$ adalah 10,4\%, sedangkan kadar air akhir cabai merah perlakuan blanching dengan larutan natrium metabisulfit pada konsentrasi 0,2 dan $0,3 \%$ adalah $6,9 \%$.

Berdasarkan Gambar 6 dapat dilihat bahwa pada hari kedua pengeringan terdapat perbedaan laju pengeringan yang jelas antar perlakuan variasi konsentrasi larutan natrium metabisulfit, dimana semakin besar konsentrasi natrium metabisulfit maka semakin cepat penurunan kadar air cabai merah. Hal ini sesuai dengan pernyataan Hartuti dan Sinaga (1993) bahwa natrium merupakan zat yang mudah larut dan bersifat higroskopis, sehingga molekul Natrium akan menarik molekul air. Dengan menjadi lunaknya buah cabai dan tertariknya sebagian molekul air oleh molekul natrium menyebabkan air dari jaringan sel akan lebih mudah keluar waktu di lakukan pengeringan.

\section{Vitamin C Cabai Merah}

Kandungan vitamin $\mathrm{C}$ cabai merah segar sebelum pengeringan yaitu sebesar 39,6 $\mathrm{mg} / 100 \mathrm{~g}$. Kandungan vitamin $\mathrm{C}$ cabai merah kering dengan perlakuan blanching dalam larutan natrium metabisulfit dapat dilihat pada Gambar 7. Kandungan vitamin $\mathrm{C}$ cabai merah kering pada perlakuan blanching dalam larutan natrium metabisulfit dengan konsentrasi $0,2 \%$ yaitu sebesar 30,8 mg/100gram. Sedangkan kandungan vitamin C cabai merah kering pada perlakuan blanching dalam larutan natrium metabisulfit dengan konsentrasi 0,3\% yaitu sebesar $22 \mathrm{mg} / 100$ gram dan kandungan vitamin $\mathrm{C}$ cabai merah kering pada perlakuan blanching dalam larutan natrium metabisulfit dengan konsentrasi $0 \%$ yaitu sebesar 26,4 mg/100gram.Sesuai dengan penyataan Almatsier (2001)bahwa vitamin C mudah larut dalam air dan mudah rusak akibat pemanasan. Penurunan kadar vitamin $\mathrm{C}$ pada cabai merah kering dapat dijelaskan sebagai akibat proses pengeringan dimana bahan terpapar pada temperatur pengeringan.

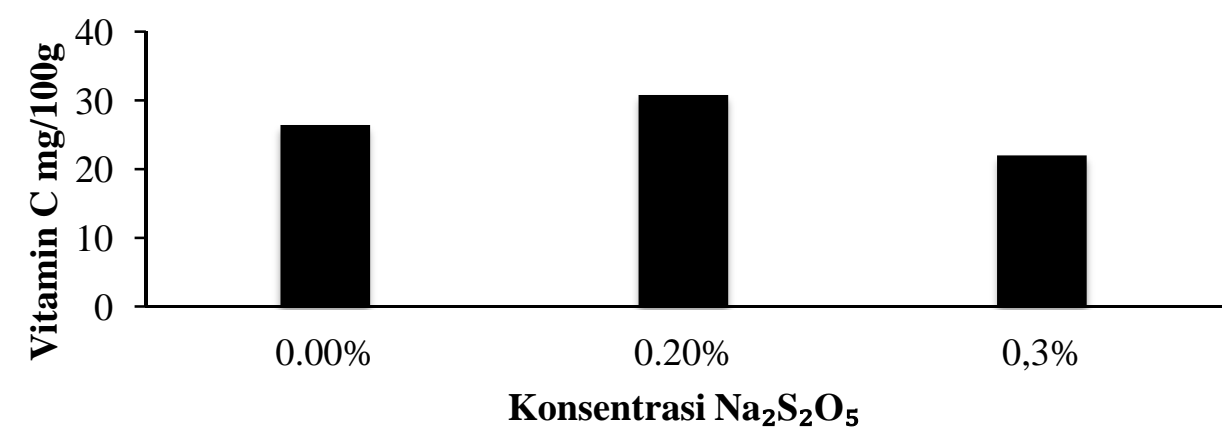

Gambar 7. Kandungan Vitamin C Cabai Merah Kering Akibat Perlakuan Blanching Dengan Variasi Konsentrasi Larutan Natrium Metabisulfit

\section{Rendemen}

Rendemen cabai merah tertinggi diperoleh pada perlakuan blanching dalam larutan natrium metabisulfit dengan konsentrasi $0 \%$ yaitu sebesar 22,01\%. Sedangkan rendemen terendah didapat padaperlakuan blanching dalam larutan natrium metabisulfit dengan 
konsentrasi $0,3 \%$ sebesar 20,74\%. Sedangkan nilai rendemen pada perlakuan blanching dalam larutan natrium metabisulfit dengan konsentrasi $0,2 \%$ yaitu sebesar $21,52 \%$.

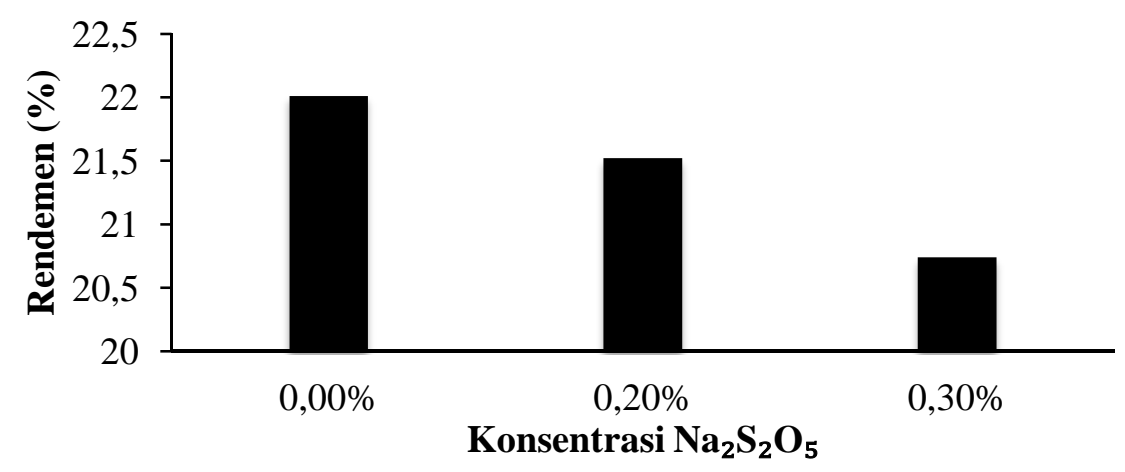

Gambar 8. Rendemen Cabai Merah Kering Akibat Perlakuan Blanching Dengan Larutan Natrium Metabisulfit

Rendemen yang diperoleh tentunya berbanding terbalik dengan kadar air. Seperti telah dijelaskan sebelumnya, peningkatan konsentrasi larutan natrium metabisulfit menyebabkan penurunan kadar air yang lebih besar sehingga menghasilkan rendemen yang rendah.

\section{Warna}

Hasil analisis warna cabai merah kering menunjukkan bahwa nilai L yang dihasilkan berkisar antara 54,41 sampai 57,97. Nilai L terendah diperoleh dari cabai merah perlakuan blanching dalam larutan natrium metabisulfit dengan konsentrasi $0,3 \%$, sedangkan nilai $\mathrm{L}$ tertinggi diperoleh cabai merah perlakuan blanching dalam larutan natrium metabisulfit dengan konsentrasi $0,2 \%$.

Nilai a* yang dihasilkan berkisar antara 26,41 sampai 42,86 . Nilai a yang terendah diperoleh dari cabai merah perlakuan blanching dalam larutan natrium metabisulfit dengan konsentrasi $0 \%$ sedangkan nilai a tertinggi diperoleh pada cabai merah perlakuan blanching dalam larutan natrium metabisulfit dengan konsentrasi $0,2 \%$.

Nilai b yang dihasilkan berkisar antara 17,22 sampai 28,75 . Nilai b yang terendah diperoleh dari cabai merah perlakuan blanching dalam larutan natrium metabisulfit dengan konsentrasi $0 \%$, sedangkan nilai $\mathrm{b}$ tertinggi diperoleh cabai merah perlakuan blanching dalam larutan natrium metabisulfit dengan konsentrasi $0,2 \%$. Grafik nilai L*a*b dapat dilihat pada Gambar 9.

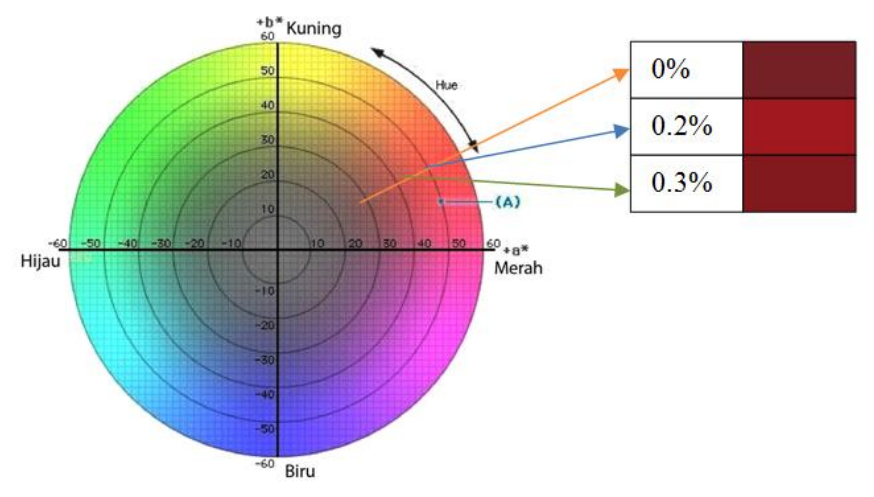

Gambar 9. Grafik nilai L*a*b Cabai Merah Kering 


\section{KESIMPULAN DAN SARAN}

Pengeringan menggunakan alat pengering tipe Hohenheim berlangsung dengan kisaran temperatur pengeringan $42-62{ }^{\circ} \mathrm{C}, \mathrm{RH} 26-78 \%$, dan kecepatan udara yang sangat rendah, walaupun terjadi fluktuasi iradiasi surya, kondisi dalam ruang pengering dapat dipertahankan untuk berlangsungnya proses pengeringan. Peningkatan konsentrasi larutan natrium metabisulfit mempercepat penurunan kadar air sehingga mempercepat proses pengeringan. Vitamin $\mathrm{C}$ cabai kering menurun setelah pengeringan sebagai akibat terpaparnya cabai kering terhadap temperatur pengeringan, dimana polanya tidak dapat dijelaskan sebagai pengaruh konsentrasi larutan natrium metabisulfit. Rendemen cabai kering menurun dengan peningkatan konsentrasi larutan natrium metabisulfit yang merupakan efek kontras dari pencapaian kadar air. Berdasarkan analisis warna, warna tercerah diperoleh pada cabai merah kering perlakuan blanching dalam larutan natrium metabisulfit dengan konsentrasi $0,2 \%$. Perlu dilakukan penelitian lanjutan dengan variasi senyawa anorganik lain dalam proses blanching untuk meningkatkan mutu cabai merah kering.

\section{DAFTAR PUSTAKA}

Ali, A., Yusmarini dan I. Solihah. 2002. Pengaruh Konsentrasi Natrium Metabisulfit dan Lama Blanching terhadap Mutu Cabai Merah (Capsicum annum L.) Kering. Jurnal SAGU Vol.1 No.1. Fakultas Pertanian, Universitas Riau, Pekanbaru

Almatsier, S. 2001. Prinsip Dasar Ilmu Gizi. Gramedia Pustaka Utama, Jakarta.

Gayo, A. 2015. Kajian Keseragaman Kualitas Pliek U pada Pengeringan Dengan Meggunakan Alat Pengering Tipe Hohenheim. Skripsi. Program Studi Teknik Pertanian Fakultas Pertanian, Universitas Syiah Kuala, Banda Aceh.

Hartuti, N dan R.M. Sinaga. 1993. Pengaruh Bahan Pencelup dan Tingkat Kematangan terhadap Mutu Cabai Rawit (Capsicum frutuscens L.) Kering Buletin Penelitian Hortikultura Lembang, Bandung.

Taib, G., Said, G., dan Wiraatmadja, S. 1988. Operasi Pengeringan pada Pengolahan Hasil Pertanian. PT Mediyatama Sarana Perkasa, Jakarta.

Thahir, R. 1988. Teknologi Pasca Panen Jagung. Pusat Penelitian dan Pengembangan Tanaman Pangan, Bogor.

Yani, S dan D. A. Ratriningsih. 1997. Pengeringan Cabai. Penebar Swadaya,Jakarta. 